\title{
絨毛癌細胞 $(\mathrm{BeWo})$ の $\mathrm{hCG}(\alpha, \beta)$ 生成, 分泌制御機構における細胞内刺激伝達系の役割
}

\author{
神戸大学医学部産科婦人科学教室 \\ (指導 望月黃人教授) \\ 西 野 理一郎, 丸 尾猛 \\ 松 尾 博 哉, 望 月 畺 人
}

The Role of Signal Transduction Systems in the

Regulation of the Production and Secretion of hCG

$(\alpha, \beta)$ by Cultured Human Choriocarcinoma Cells (BeWo)

\section{Riichiro NISHINO, Takeshi MARUO, Hiroya MATSUO and Matsuto MOCHIZUKI}

\author{
Department of Obstetrics and Gynecology, \\ Kobe University School of Medicine, Kobe 650, Japan \\ (Director: Professor Matsuto Mochizuki)
}

The BeWo cell line, derived from choriocarcinoma, produces and releases human chorionic gonadotropin (hCG) and its $\alpha$-and $\beta$-subunits. The authors have already reported that cAMP and EGF stimulated the production and secretion of hCG and its subunits by cultured BeWo cells. Therefore, in order to elucidate the role of signal transduction systems (cAMP-A-kinase system, DG-C-kinase system and $\mathrm{Ca}^{2+}$-calmodulin system) in the regulation of hCG $(\alpha, \beta)$ synthesis by human choriocarcinoma cells, effects of cholera toxin $(\mathrm{CT})$, an activator of adenylate cyclase, phorbol 12-myristate 13-acetate (PMA), a protein kinase $\mathrm{C}$ activator, and $\mathrm{Ca}^{2+}$ ionophore $\mathrm{A} 23187$, an activator of $\mathrm{Ca}^{2+}$ modulation on hCG $(\alpha, \beta)$ production and secretion by BeWo cells cultured in a serum - free condition were evaluated. Immunoreactive hCG $\alpha, \mathrm{hCG} \beta$ and hCG in the media and cultured cells were measured by each homologous RIA for hCG $\alpha$, hCG $\beta$ and hCG, respectively.

Addition of $\mathrm{CT}$ at a concentration of $100 \mathrm{ng} / \mathrm{ml}$ into the medium caused extreme increases in the cellular levels of hCG $\alpha, \mathrm{hCG} \beta$ and hCG together with remarkable increases in $\mathrm{hCG} \alpha, \mathrm{hCG} \beta$ and hCG levels in the medium. This stimulatory effect of CT was first observed on the increase of hCG $\alpha$ levels in cultured BeWo cells and medium at $3 \mathrm{~h}$, then observed on the increase of hCG $\beta$ levels at $6 \mathrm{~h}$ and was last detectable on the increase of hCG levels in the cultured cells and medium at 12h. Addition of PMA at a concentration of $100 \mathrm{ng} / \mathrm{ml}$ into the medium caused an increase in the cellular and medium levels of hCG $\alpha$, 
hCG $\beta$ and hCG shortly (3h) after the exposure to PMA. Addition of A23187 at a concentration of $100 \mathrm{ng} / \mathrm{ml}$ into the medium caused a slight increase in hCG $\alpha$ levels in the medium at $6 \mathrm{~h}$ without accompanying the increase in those cellular levels. When added together, PMA potentiated the stimulatory effect of CT on hCG $\alpha$, hCG $\beta$ and hCG levels in the cultured BeWo cells and medium, while PMA did not potentiate the effect of A23187 in this experimental condition.

These findings suggest that cAMP-A-kinase system plays a major role in the signal transduction of hCG $(\alpha, \beta)$ synthesis and secretion by BeWo choriocarcinoma cells, and that DG-C-kinase system interacts synergistically with cAMP-A-kinase system in the regulation of hCG $(\alpha, \beta)$ synthesis and secretion by BeWo cells. $\mathrm{Ca}^{2+}$-calmodulin system appears to participate in the regulation of $\mathrm{hCG} \alpha$ secretion without affecting the synthesis of hCG $(\alpha, \beta)$ in BeWo cells.

\section{I 緒言}

細胞に対する外因性刺激とそれに対する細胞応答に関する研究は, cyclic AMP (cAMP) の発見 以来急速に進展し, 現在, 少なくとも, 細胞内刺激伝達機構として, cAMP 依存性 protein kinase (cAMP - A - kinase 系), $\mathrm{Ca}^{2+}$ - calmodulin 系ならびに西塚 ${ }^{1718)}$, 高井ら ${ }^{9120}$ により提唱された diacy lglycerol-C-kinase 系 (DG-C-kinase 系) など3種の伝達系の存在が知られるようになった。

これらの系のうち, 特にDG-C-kinase 系は, 細胞外シグナルが受容体に結合したあと phospholipase Cの作用によって phosphoinositide から DG が生成され ${ }^{1124)}$, この DG が生理的濃度の $\mathrm{Ca}^{2+}$ の存在下に細胞膜リン脂質 (phosphatidylserine) と協同してC-kinase を活性化させ ${ }^{1625)}$, 活 性化された C-kinase の触媒作用が種々の蛋白質をリン酸化するという, DG ger とした新しい細胞膜受容伝達機構である。

いずれにしても，細胞外シグナルに対する細胞応答は多彩であり，C-kinase や A-kinase なら びに $\mathrm{Ca}^{2+}$ 受容蛋白質の作用点もそれぞれの細胞によって異なっていると考兄られる。

著者ら ${ }^{2) 14}$ はすでに, 絨毛癌細胞由来の cell line である BeWo 細胞において cAMPならびに $\mathrm{EGF}$ 添加が, 培養液内ならびに培養細胞内 $\mathrm{hCG}(\alpha, \beta)$ レベルをそれぞれ著明に増加させ, cAMP では添加開始後早期に, 他方, C-kinase 系を活性化させる ${ }^{99} \mathrm{EGF}$ の添加では添加終了後約 24時間の lag time を経て, hCG $(\alpha, \beta)$ レベルの増加が起こるといら事象を報告した。

そこで著者らは, 絨毛癌細胞 $(\mathrm{BeWo})^{19}$ における $\mathrm{hCG}(\alpha, \beta)$ 生成分泌制御機構に果たす cAMP-A-kinase 系, $\mathrm{Ca}^{2+}$ - calmodulin 系ならびに DG-C-kinase 系の役割とその相互関係を明 らかにする目的で, cAMP-A-kinase 系の促進物質である cholera toxin ${ }^{6)}, \mathrm{Ca}^{2+}$-calmodulin 系の 促進物質である $\mathrm{Ca}^{2+}$ ionophore A23187 ${ }^{21)}$ ならびに DG-C-kinase 系の促進物質である phorbol myristate acetate ${ }^{8)}$ の同時系統的添加比較実験を行った。

\section{II 材料および方法}

\section{1) 実験材料}

培養細胞としては，大日本製薬ラボラトリーより入手した絨毛癌細胞培養株 BeWo を用いた。 


\section{2）培養方法}

$\mathrm{BeWo}$ 細胞の培養は, $\mathrm{CO}_{2}$-incubator (Astec Co., $\mathrm{BL}$ - 320) 内で $37^{\circ} \mathrm{C}, 5 \% \mathrm{CO}_{2}-95 \%$ air の条件 下に行い，培養液としては $10 \%$ fetal bovine serum (FBS), 50\% Waymouth, 40\% Gey's balanced salt solution を用いた。すなわち，まず $10 \% \mathrm{FBS}$ 含有培養液を用いて細胞数 5 万個 $/ \mathrm{ml}$ に調 整された BeWo 細胞懸濁液の $2 \mathrm{ml}$ を 12 well tissue culture cluster (Costar Corp.) の1 well ごとに 散布して培養を開始し，位相差顕微鏡（Nikon Corp.,diaphot TMD）による観察でほぼ50\%の confluency となった時点で培養液を $10 \%$ FBS 含有培地から無血清培地へ交換し, cholera toxin (CT)， $\mathrm{Ca}^{2+}$ ionophore A23187（A23187）ならびに phorbol myristate acetate (PMA)をそれぞれ 24時間添加し，培養液内ならびに培養細胞内 $\mathrm{hCG}(\alpha, \beta)$ レベルに及ぼす影響を検討した。

BeWo 細胞培養系に添加された cholera toxin (Calbiochem Hoechst Co.Ltd ., vibrio cholerae Type Inaba) は $1 \mathrm{mg}$ を蒸留水 $1 \mathrm{ml}$ で溶解し, membrane filter (Sartorius GmbH., pore size: $0.2 \mu \mathrm{m}$ ) にて濾過隇菌したものを用い, 他方, $\mathrm{Ca}^{2+}$ ionophore A23187 (Sigma Chemical Co.) と phorbol myristate acetate (Sigma Chemical Co.) はいずれも $1 \mathrm{mg}$ を共に $99.5 \%$ ethanol $1 \mathrm{ml}$ で 溶解し，同様に濾過隇菌した物を用いた。

3）培養液内ならびに培養細胞内 hCG $(\boldsymbol{\alpha}, \boldsymbol{\beta})$ の測定

培養液内 immunoreactive hCG $\alpha$, hCG $\beta$, hCG 抗 hCG 血清を用いて確立したそれぞれの homologous RIA 系 ${ }^{12)}$ とって測定し，hCG $\alpha, h C G \beta$, hCG の分泌レベルは，すべて BeWo 細胞1万個24時間あたりの分泌量に換算して表現した。

培養細胞内 $\mathrm{hCG} \alpha$, hCG $\beta$, hCG レベルは，培養細胞を sonicator (Kontes Co.Ltd.,microultrasonic cell disrupter) にて超音波処理し, 低温遠心分離器 (Hitachi Co.Ltd.,20PR-52D) にて $3000 \mathrm{rpm}, 15$ 分間遠心分離して得られた上清中の immunoreactive hCG $\alpha$, hCG $\beta$, hCG をそれ ぞれの homologous RIA 系で測定することによって求め, すべて BeWo 細胞1万個あたりの量に 換算して表現した。

\section{4) 統計学的検討}

各群のデータは mean \pm SD にて表現し，有意差の検定は，Student'st-testによって行い， $\mathrm{P}<0.05$ を有意水準とした。

\section{III 実 験 成 績}

\section{1） BeWo 細胞の hCG $(\boldsymbol{\alpha}, \boldsymbol{\beta})$ 分泌レベルに及ばす影響}

\section{a) cholera toxin (CT) の影響}

$\mathrm{hCG} \alpha$ 分泌レベルは CT 添加によって用量依存的に増加し, CT $100 \mathrm{ng} / \mathrm{ml}$ 添加系での hCG $\alpha$ 分 泌レベルは CT 添加開始後3時間で control に比し有意に増加し $(\mathrm{P}<0.01), 24$ 時間の CT 添加終了 から24時間後で control の約6.4倍，48時間後では約12倍に増加した（Fig.1)。

また, $\mathrm{hCG} \beta$ 分泌レベルも CT 添加によって用量依存的に増加し, CT 100ng/ml 添加系での $\mathrm{hCG} \beta$ 分泌レベルは CT 添加開始後6時間で control に比し有意に増加し $(\mathrm{P}<0.01), 24$ 時間の CT 添加終了から24時間後で control の約6倍，48時間後では約13倍に増加した。

hCG 分泌レベルも CT 添加によって用量依存的に増加し, CT $100 \mathrm{ng} / \mathrm{ml}$ 添加系での hCG 分泌 レベルは CT 添加開始後12時間より著増し $(\mathrm{P}<0.01), \mathrm{CT} 24$ 時間添加終了から24時間後で control の約21倍，48時間後では約40倍に増加した（Fig.2）。 


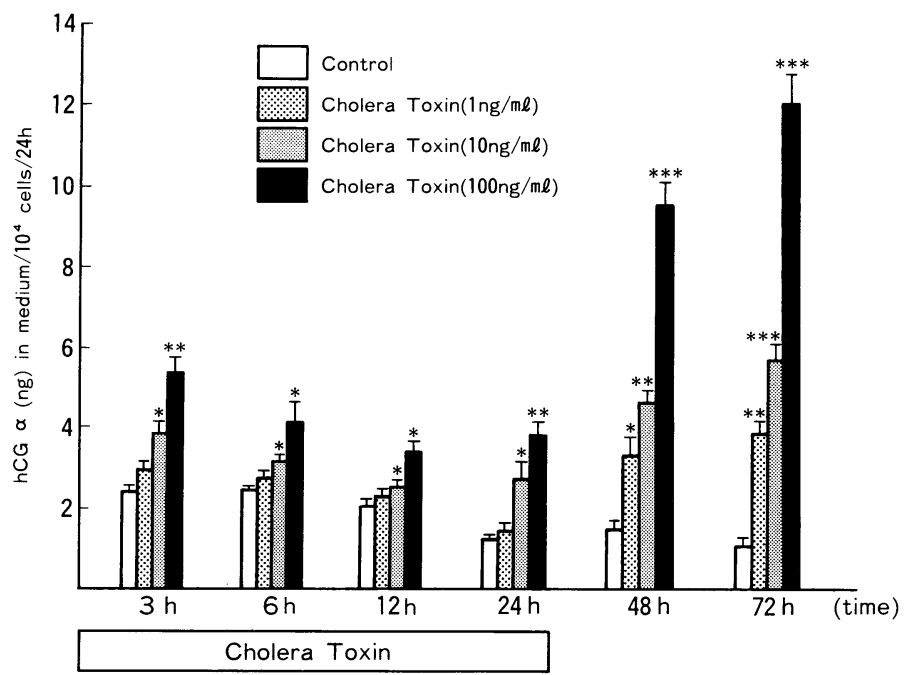

Fig. 1 Effect of Cholera Toxin on immunoreactive hCG $\alpha$ release into the medium per $10^{4}$ cells in cultures of BeWo cells. Values are the mean $\pm \mathrm{SD}$ of triplicate cultures. Asterisks indicate significant differences from control values: $*, \mathrm{P}<0.05 ; * *, \mathrm{P}<0.01 ; * * *$, reliable at least to a level of $\mathrm{P}<0.005$.

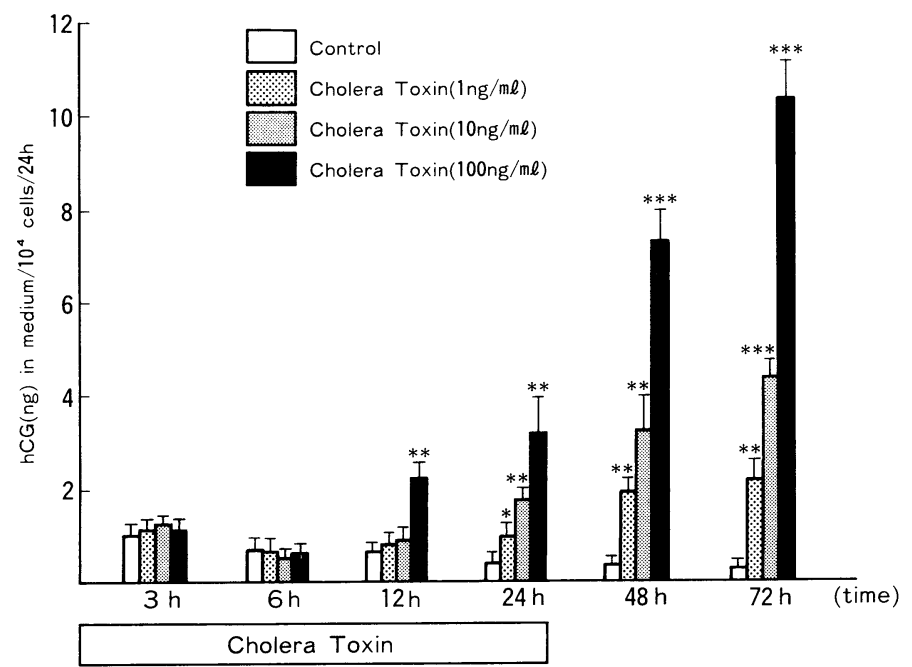

Fig. 2 Effect of Cholera Toxin on immunoreactive hCG release into the medium per $10^{4}$ cells in cultures of BeWo cells. Values are the mean $\pm \mathrm{SD}$ of triplicate cultures. Asterisks indicate significant differences from control values: $*, \mathrm{P}<0.05 ; * *, \mathrm{P}<0.01 ; * * *$, reliable at least to a level of $\mathrm{P}<0.005$. 


\section{b) phorbol myristate acetate (PMA) の影響}

$\mathrm{hCG} \alpha$ 分泌レベルならびに hCG $\beta$ 分泌レベルは PMA 添加開始後3時間でいずれも用量依存的増 加を示し, PMA $100 \mathrm{ng} / \mathrm{ml}$ 添加系での hCG $\alpha$ 分泌レベルは control の約 2.4 倍, hCG $\beta$ 分泌レベ ルは control の約3.2倍にそれぞれ増加したが，以後の $\mathrm{hCG} \alpha, \mathrm{hCG} \beta$ 分泌促進効果は軽微であっ た (Fig.3)。

また，hCG 分泌レベルは PMA 添加により，添加開始後早期に，3時間で用量依存的増加を示し， PMA 100ng/ml 添加系での hCG 分泌レベルは control の約3倍に増加した (Fig.4)。この PMA 添 加に伴う hCG 分泌レベルの増加は PMA 添加開始後早期（3時間）に最も顕著で，以後の hCG 分 泌促進効果は軽微であった。

\section{c) $\mathrm{Ca}^{2+}$ ionophore A23187 (A23187) の影響}

$\mathrm{hCG} \alpha$ 分泌レベルは，A23187 100 $\mathrm{ng} / \mathrm{ml}$ 添加開始後6時間の時点で用量依存的増加を示したが $(\mathrm{P}<0.01)$ ，以後は A23187 添加に伴う有意な変化を示さなかった（Fig.5）。しかし，hCGならび に hCG $\beta$ 分泌レベルは A23187 添加に伴う有意な変化を示さなかった。

d) cholera toxin (CT), phorbol myristate acetate (PMA), Ca ${ }^{2+}$ ionophore A23187 (A23187) の相 互作用

$\mathrm{CT} 100 \mathrm{ng} / \mathrm{ml}$ 添加に伴う hCG $\alpha, \mathrm{hCG} \beta, \mathrm{hCG}$ 分泌レベルの増加は, PMA $100 \mathrm{ng} / \mathrm{ml}$ を同時 に添加することによって一層顕著となることを認めた。

すなわち, CT と PMA 同時添加に伴う hCG $\alpha$ (Fig.6), hCG $\beta$ (Fig.7) ならびに hCG 分泌レ ベルの相加的増加は，24時間にわたる CT と PMA 同時添加終了から 24 時間経過後に最大となり, control に比し, hCG $\alpha$ の分泌は約7.6倍, hCG $\beta$ の分泌は約10倍, hCG の分泌は約27倍へとそれ

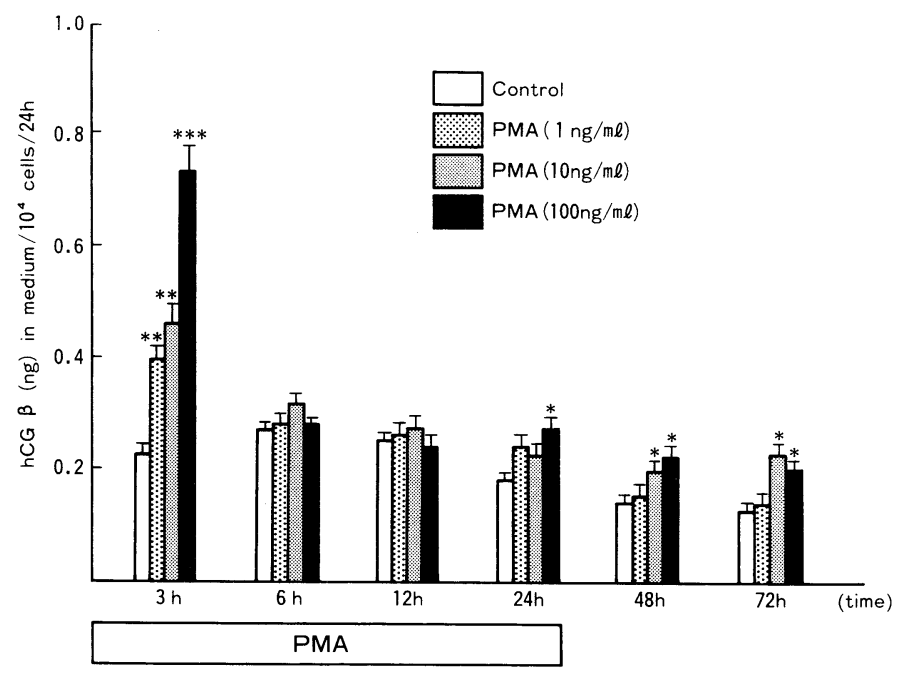

Fig. 3 Effect of PMA on immunoreactive hCG $\beta$ release into the medium per $10^{4}$ cells in cultures of BeWo cells. Values are the mean $\pm \mathrm{SD}$ of triplicate cultures. Asterisks indicate significant differences from control values: $*, \mathrm{P}<0.05 ; * *, \mathrm{P}<0.01 ; * * *$, reliable at least to a level of $\mathrm{P}<0.005$. 
ぞれ増加し，また, CT 単独添加に比し, hCG $\alpha$ の分泌は約1.4倍, hCG $\beta$ の分泌は約1.7倍, hCG の分泌は約1.3倍にそれぞれ増加した。

しかし，A23187と PMA 同時添加に伴う相加的な分泌促進効果は hCG $\alpha, \mathrm{hCG} \beta$ ならびに hCG 共に観察されなかった。

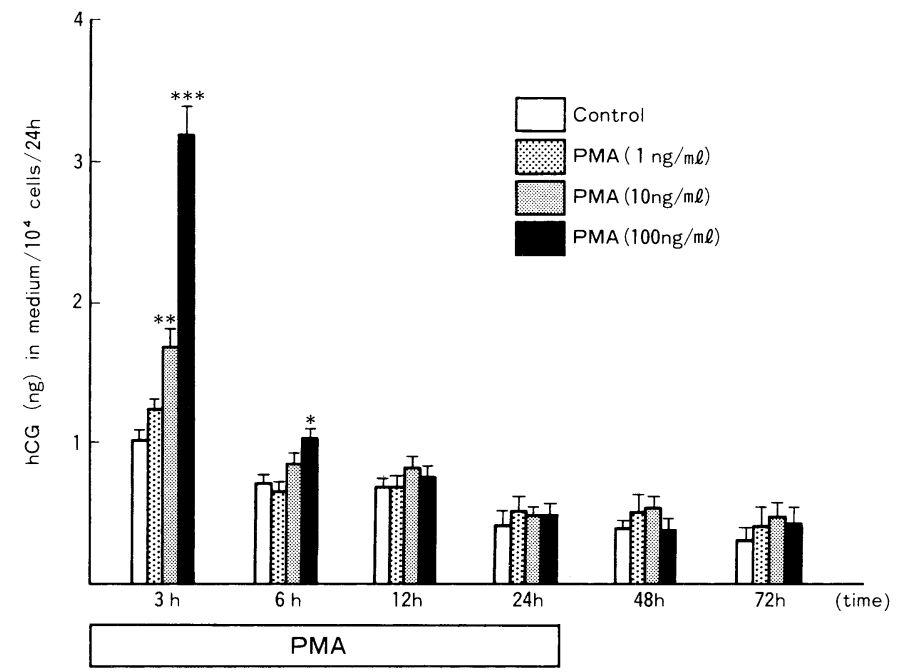

Fig. 4 Effect of PMA on immunoreactive hCG release into the medium per $10^{4}$ cells in cultures of BeWo cells. Values are the mean $\pm \mathrm{SD}$ of triplicate cultures. Asterisks indicate significant differences from control values: $*, \mathrm{P}<0.05 ; * *, \mathrm{P}<0.01 ; * * *$, reliable at least to a level of $\mathrm{P}<0.005$.

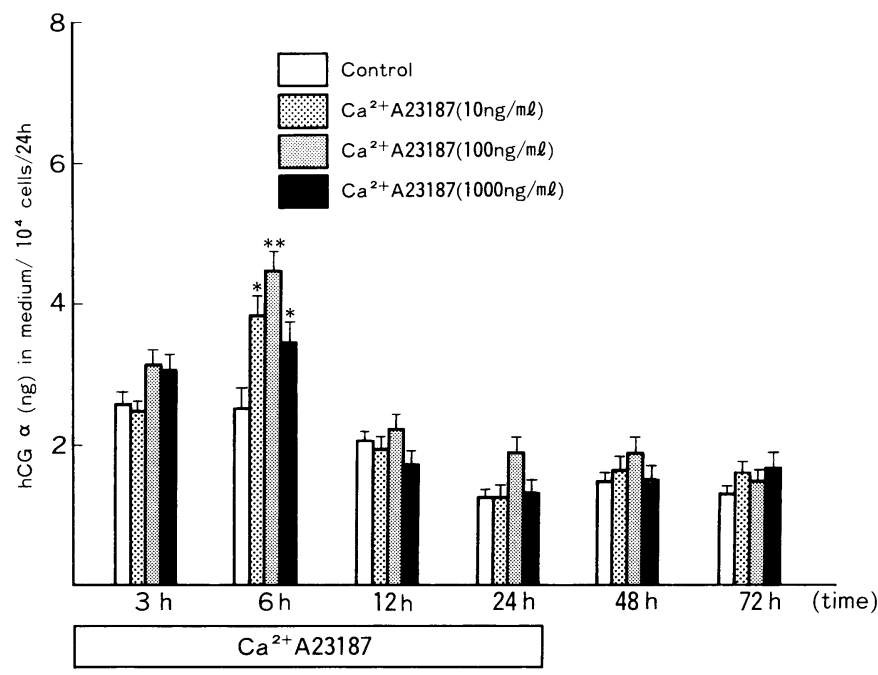

Fig. 5 Effect of $\mathrm{Ca}^{2+}$ ionophore (A23187) on immunoreactive hCG $\alpha$ release into the medium per $10^{4}$ cells in cultures of BeWo cells. Values are the mean $\pm \mathrm{SD}$ of triplicate cultures. Asterisks indicate a significant difference from control value: $*, \mathrm{P}<0.05 ; * *, \mathrm{P}<0.01$. 


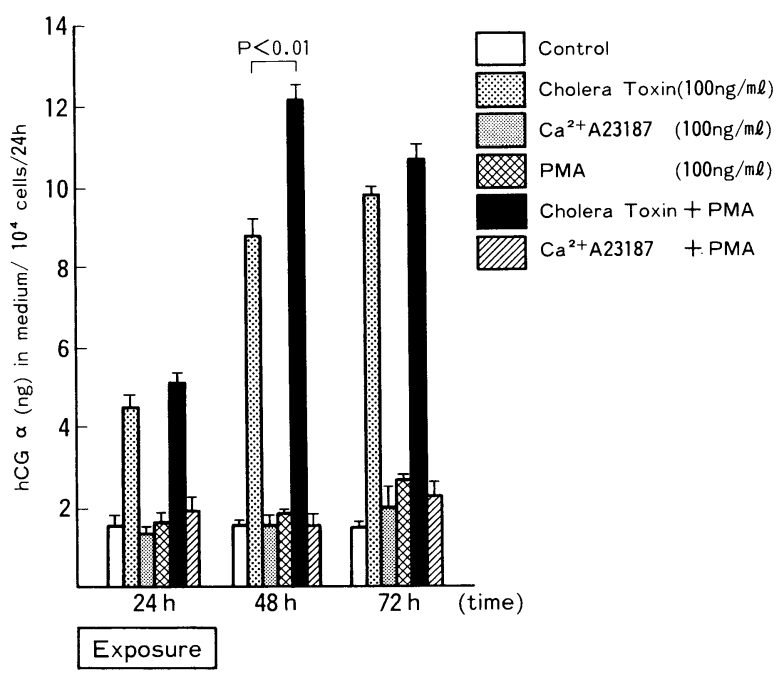

Fig. 6 Co-operative effects of Cholera Toxin, PMA and $\mathrm{Ca}^{2+}$ ionophore (A23187) on immunoreactive hCG $\alpha$ release into the medium per $10^{4}$ cells in cultures of BeWo cells. Values are the mean $\pm \mathrm{SD}$ of triplicate cultures.

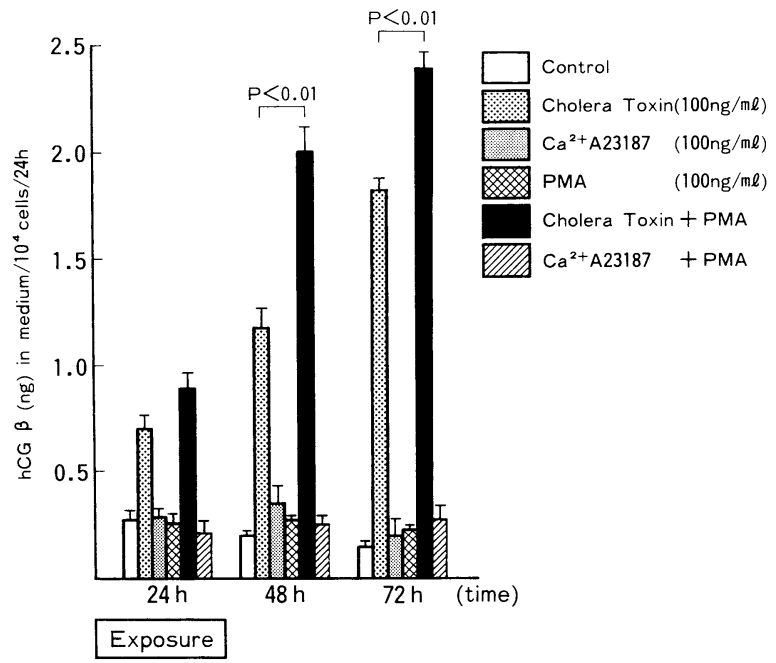

Fig. 7 Co-operative effects of Cholera Toxin, PMA and $\mathrm{Ca}^{2+}$ ionophore (A23187) on immunoreactive hCG $\beta$ release into the medium per $10^{4}$ cells in cultures of BeWo cells. Values are the mean $\pm \mathrm{SD}$ of triplicate cultures. 


\section{2） BeWo 細胞の細胞内 hCG $(\boldsymbol{\alpha}, \boldsymbol{\beta})$ レベルに及ばす影響}

\section{a) cholera toxin (CT) の影響}

細胞内 hCG $\alpha$ レベルは, CT 添加開始後3時間より CT 添加量と用量反応的に増加しはじめ $(\mathrm{P}<$ 0.01), CT $100 \mathrm{ng} / \mathrm{ml}$ 添加系では24時間にわたる CT 添加終了から 24 時間後の時点で control の約 14倍, CT 添加終了から48時間後の時点では control の約11倍へと増加し, CT 添加に伴い細胞内 hCG $\alpha$ レベルが著増することを認めた（Fig.8)。

他方, 細胞内 hCG $\beta$ レベルは, CT 添加開始後6時間より増加し $(\mathrm{P}<0.01), \mathrm{CT} 100 \mathrm{ng} / \mathrm{ml}$ 添加 系では24時間にわたるCT 添加終了から48時間後の時点で control の約8倍に著増した（Fig.9）。

また, 細胞内 hCG レベルは, CT 添加開始後 12 時間より CT 添加量と用量依存的増加を示し, $\mathrm{CT} 100 \mathrm{ng} / \mathrm{ml}$ 添加系では24時間にわたる CT 添加終了から 24 時間後の時点で control の約11倍, CT 添加終了から 48 時間後の時点では control の約 20 倍へと増加し, CT 添加に伴って細胞内 hCG レベルが著増することを認めた（Fig.10）。

\section{b) phorbol myristate acetate (PMA) の影響}

細胞内 hCG $\alpha, h C G \beta$ ならびに hCG レベルは PMA 添加開始後早期に3時間で，いずれも用量 依存的増加を示し, PMA 100ng $/ \mathrm{ml}$ 添加によって細胞内 hCG $\alpha$ レベルは control の約 2.3 倍, 細胞 内 hCG $\beta$ レベルは control の約14倍, 細胞内 hCG レベルは control の約1.9倍へとそれぞれ増加

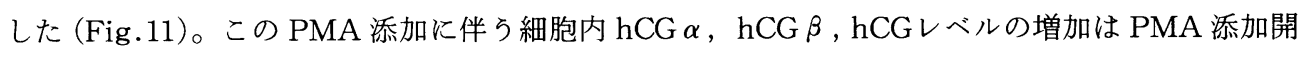
始後3時間において最大であり，その促進効果は PMA 添加開始後6時間まで軽度ながら観察された が，それ以後PMA 添加に伴ら有意な変化は観察されなかった。

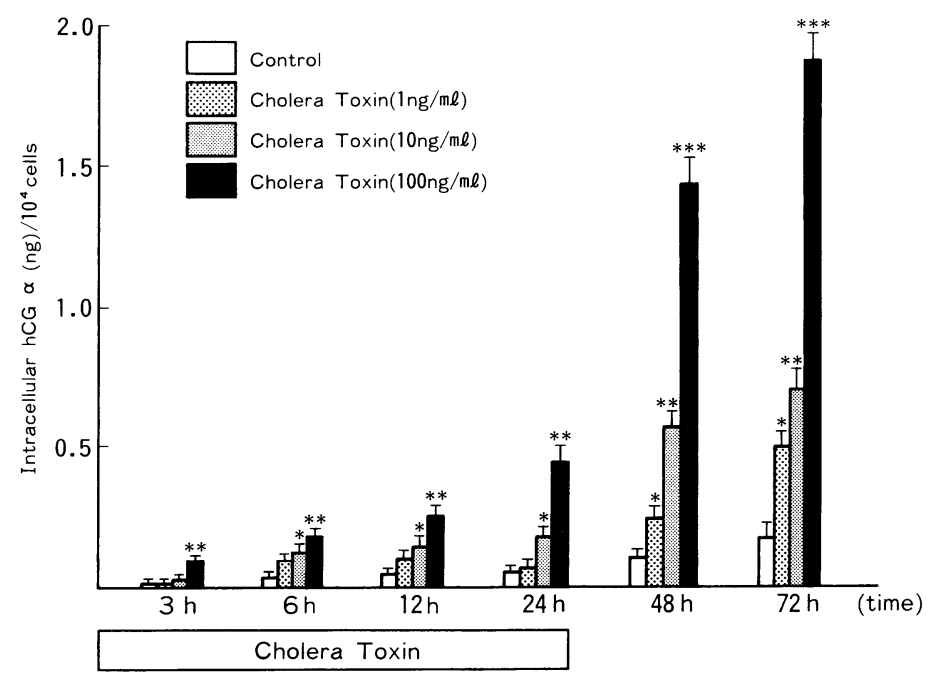

Fig. 8 Effect of Cholera Toxin on intracellular immunoreactive hCG $\alpha$ levels per $10^{4}$ cells in cultures of BeWo cells. Values are the mean $\pm \mathrm{SD}$ of triplicate cultures. Asterisks indicate significant differences from control values: $*, \mathrm{P}<0.05 ; * *, \mathrm{P}<0.01 ; * * *$, reliable at least to a level of $\mathrm{P}<0.005$. 


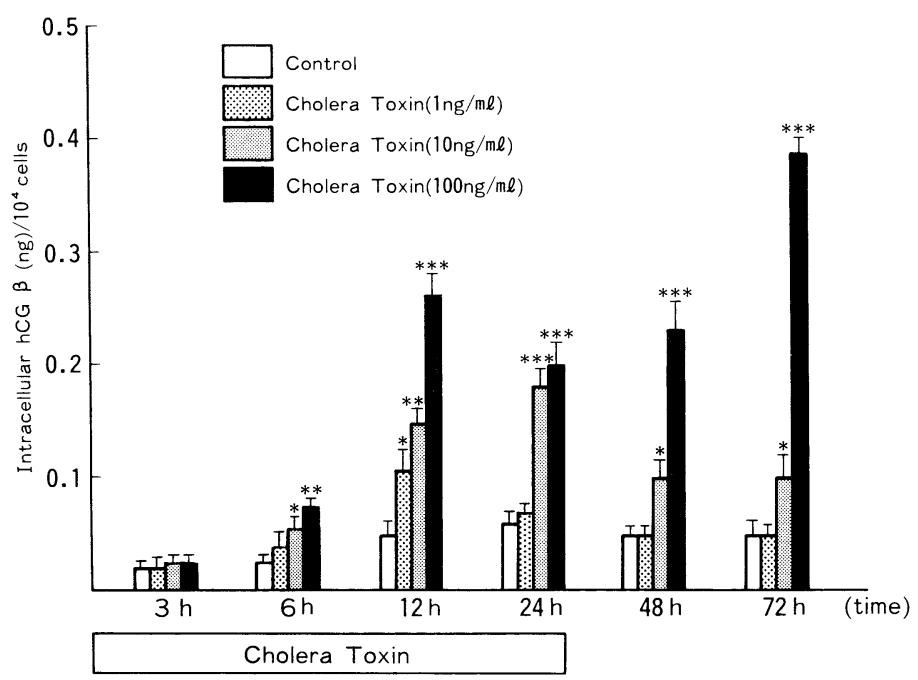

Fig. 9 Effect of Cholera Toxin on intracellular immunoreactive hCG $\beta$ levels per $10^{4}$ cells in cultures of BeWo cells. Values are the mean \pm SD of triplicate cultures. Asterisks indicate significant differences from control values: $*, \mathrm{P}<0.05 ; * *, \mathrm{P}<0.01 ; * * *$, reliable at least to a level of $\mathrm{P}<0.005$.

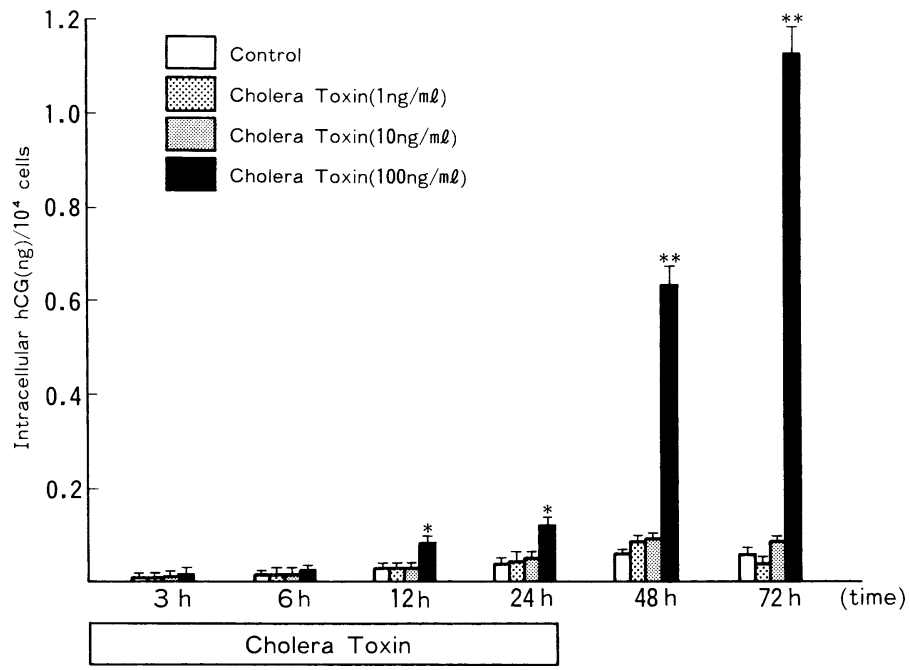

Fig. 10 Effect of Cholera Toxin on intracellular immunoreactive hCG levels per $10^{4}$ cells in cultures of BeWo cells. Values are the mean $\pm \mathrm{SD}$ of triplicate cultures. Asterisks indicate significant differences from control values: $*, \mathrm{P}<0.01 ; * *$, reliable at least to a level of $\mathrm{P}<0.005$. 


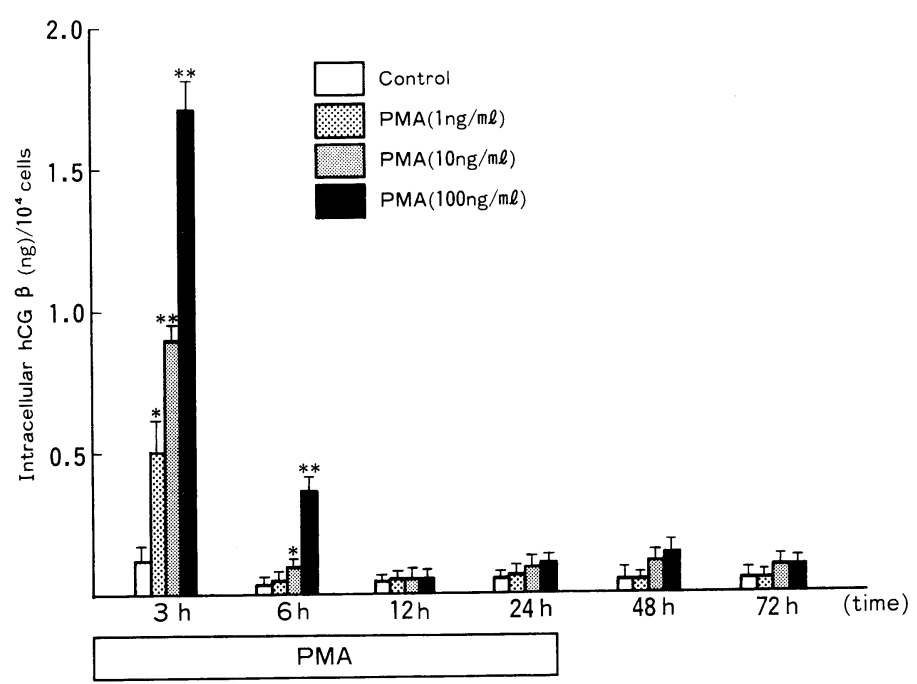

Fig. 11 Effect of PMA on intracellular immunoreactive hCG $\beta$ levels per $10^{4}$ cells in cultures of BeWo cells. Values are the mean $\pm \mathrm{SD}$ of triplicate cultures. Asterisks indicate significant differences from control values: $*, \mathrm{P}<0.01 ; * *$, reliable at least to a level of $\mathrm{P}<0.005$.

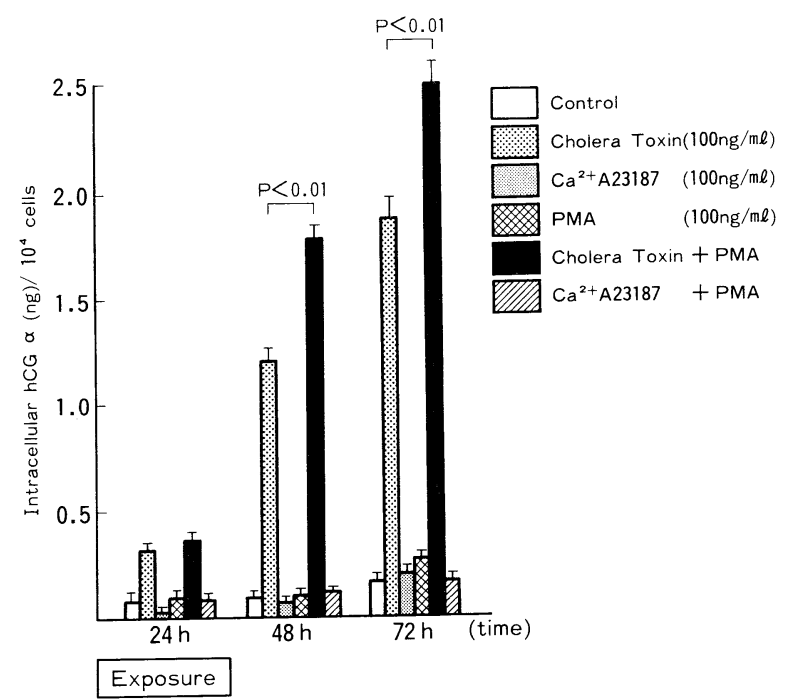

Fig. 12 Co-operative effects of Cholera Toxin, PMA and $\mathrm{Ca}^{2+}$ ionophore (A23187) on intracellular immunoreactive hCG $\alpha$ levels per $10^{4}$ cells in cultures of BeWo cells. Values are the mean $\pm \mathrm{SD}$ of triplicate cultures. 


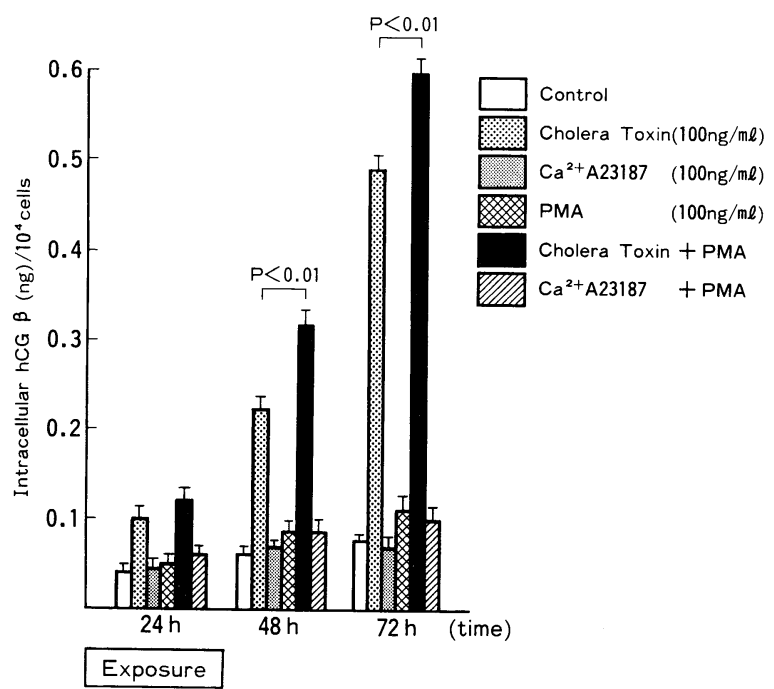

Fig. 13 Co-operative effects of Cholera Toxin, PMA and $\mathrm{Ca}^{2+}$ ionophore (A23187) on intracellular immunoreactive hCG $\beta$ levels per $10^{4}$ cells in cultures of BeWo cells. Values are the mean $\pm \mathrm{SD}$ of triplicate cultures.

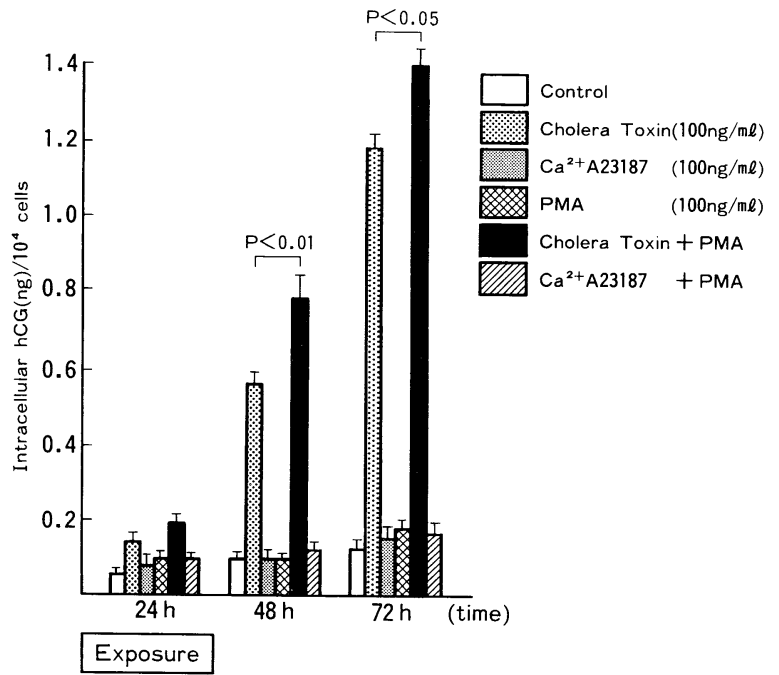

Fig. 14 Co-operative effects of Cholera Toxin, PMA and $\mathrm{Ca}^{2+}$ ionophore (A23187) on intracellular immunoreactive hCG levels per $10^{4}$ cells in cultures of BeWo cells. Values are the mean $\pm \mathrm{SD}$ of triplicate cultures. 


\section{c) $\mathrm{Ca}^{2+}$ ionophore A23187 (A23187) の影響}

細胞内 hCG $\alpha$, hCG $\beta$ ならびに hCG レベルは A23187添加による有意な影響を示さなかった。

d) cholera toxin (CT), phorbol myristate acetate (PMA), $\mathrm{Ca}^{2+}$ ionophore A23187 (A23187) の

\section{相互作用}

$\mathrm{CT} 100 \mathrm{ng} / \mathrm{ml}$ 添加に伴う細胞内 $\mathrm{hCG} \alpha, \mathrm{hCG} \beta$ ならびに hCG レベルの増加は PMA $100 \mathrm{ng} / \mathrm{ml}$ を同時に添加することによって一層顕著となることを認めた。

つまり, CT と PMA 同時添加に伴う細胞内 hCG $\alpha$ (Fig.12), hCG $\beta$ (Fig.13) ならびに hCG (Fig.14）レベルの相加的増加は，24時間にわたる CT と PMA 同時添加終了から 24 時間経過後に その増加は最大となり, control に比し, 細胞内 hCG $\alpha$ は約 20 倍, 細胞内 hCG $\beta$ は約 5.3 倍, 細胞 内 hCG は約8倍に増加し, また, CT 単独添加に比し, 細胞内 hCG $\alpha$ は約 1.5 倍, 細胞内 hCG $\beta$ は 約1.4倍, 細胞内 hCG は約1.4倍に増加した。

しかし, A23187 と PMA 同時添加に伴う細胞内 $\mathrm{hCG} \alpha, \mathrm{hCG} \beta$ ならびに hCG レベルの有意な 変化は観察されなかった。

\section{V 考察}

著者らはすでに䄉毛癌細胞 (BeWo) 培養系で, cAMP と EGF の添加実験を行い hCG, $\mathrm{hCG} \alpha$, $\mathrm{hCG} \beta$ の分泌レベルならびに細胞内レベルが cAMP では添加開始後早期に, 他方, EGF では添加 終了後約24時間の lag time を経て増加することを確認し, 報告した ${ }^{2)}$ このことより, 細胞内情報 伝達機構としての A-kinase 系及び C-kinase 系が BeWo 細胞においてそれぞれの刺激伝達機構を 担らことが推察された。それ故本研究では, cAMP-A-kinase 系を賦活する cholera toxin, DGC-kinase 系を賦活する PMA, $\mathrm{Ca}^{2+}$ uptake を促進し $\mathrm{Ca}^{2+}$ - calmodulin 系を賦活する $\mathrm{Ca}^{2+}$ ionophore (A23187) を用いて, 絨毛癌細胞の腫瘍関連抗原である $\mathrm{hCG}(\alpha, \beta)$ 産生, 分泌における cAMP-A-kinase 系, $\mathrm{Ca}^{2+}$ - calmodulin 系ならびに DG-C-kinase 系の役割とその相互作用を検 討した。

ところで, 細胞内情報伝達系において cAMP と $\mathrm{Ca}^{2+}$ は重要な second messenger であるが, cAMP は $\mathrm{Ca}^{2+}, \mathrm{DG}$ を介する受容伝達機構とは別種の受容伝達系を構成している。cAMPを介す る受容伝達系は, それ単独で細胞機能を調節するが, $\mathrm{Ca}^{2+}, \mathrm{DG}$ を介する受容伝達系と互いに協調 して同一反応を伝達する場合や，あるいは逆に互いに拮抗して作動する場合がある。この 2 種類の 受容伝達系が互いに無関係に作動するか, あるいは協調的に作動する場合は, monodirectional control $^{918)}$ と呼ばれ，逆に互いに拮抗的に作動する場合は bidirectional control ${ }^{918)}$ と呼ばれている。

今回著者らが行った実験によると, cholera toxin 添加によって hCG $\alpha$, hCG $\beta$, hCG のBeWo 細胞内レベルならびに培養液内レベルはいずれも増加することが観察され, 特に, 細胞内レベル の増加は cholera toxin 添加開始後 hCG $\alpha$ が最も早期に起こり, それにひきつづいて hCG $\beta$ さら には, hCG が増加することが認められた。この成績は, hCG $\alpha$ とCG $\beta$ の dimer である $\mathrm{hCG}^{7}$ の BeWo 細胞内生成に先立って, cholera toxin によってまず hCG $\alpha$ 生成が, 次いで hCG $\beta$ 生成が促 進され，それに引き続いて hCG 生成が促進されることを示唆し，cholera toxin によって促進され る cAMP-A-kinase が, 䋐毛癌細胞での hCG $\alpha, h C G \beta$ の生成をその mRNA 発現レベルで促進 する可能性が極めて高いといえる。また著者らの成績では, cholera toxin 添加に伴う BeWo 細胞 内 $\mathrm{hCG} \alpha, \mathrm{hCG} \beta, \mathrm{hCG}$ レベルの増加の時間的推移と $\mathrm{hCG} \alpha, \mathrm{hCG} \beta, \mathrm{hCG}$ 分泌レベルの増加 
の時間的推移との間に差がみられず, BeWo 細胞での hCG $(\alpha, \beta)$ 生成促進はただちにその分泌 促進に連動することがらかがわれた。著者らはすでにトロホブラストで生成される hCG とその subunit は細胞内に蓄積されることなく分泌されるといら特性を有し，悪性トロホブラストである 絨毛癌細胞ではその傾向が一層顕著になることを報告しているが'1315)26)，今回認めた cholera toxin 添加に伴う hCG $(\alpha, \beta)$ の生成, 分泌の連動関係は先の知見によく符号しており興味深い。

ところで, cholera toxin 添加に伴 5 BeWo 細胞内 cAMP 濃度は cholera toxin 添加後用量依存 的に増加し, cholera toxin $(1 \mathrm{ng} / \mathrm{ml})$ 添加後90分で control の約300倍, 3時間で約900倍に増加す ることをRitvos ら ${ }^{22}$ は報告している。このことは, cholera toxin 添加が, BeWo 細胞内で増加し た cAMPを介してA-kinase 系を賦活し，その結果として BeWo 細胞での hCG $\alpha, h C G \beta, h C G$ の産生, 分泌が高をることを裏付けるものである。

一方, PMA 添加によって, BeWo 細胞内 hCG $\alpha, \operatorname{hCG} \beta$, hCG レベルとその培養液内レベル は共に添加開始後早期に軽度ながら増加することや, $\mathrm{Ca}^{2+}$ ionophore A23187添加によっては, BeWo 細胞培養液内の hCG $\alpha$ レベルが添加開始後早期に軽度ながら増加することを認めた。つま り, PMA によって賦活される DG-C-kinase は BeWo 細胞での hCG $\alpha, h C G \beta, h C G$ の生成と 分泌を共に促進するが，その促進の magnitude は cAMP-A-kinase による促進の magnitude に 比較して小さく，また， $\mathrm{Ca}^{2+}$ ionophore A23187 によって賦活される $\mathrm{Ca}^{2+}-\mathrm{Ca}^{2+}$ 受容蛋白質はBeWo 細胞において hCG $\alpha$ の分泌レベルを軽度増加させるのみで，その細胞内レベルすなわち生成レベ ルには有意な影響を与えないことがうかがわれた。

さらに著者らは BeWo 細胞培養系において cholera toxin と PMA, $\mathrm{Ca}^{2+}$ ionophore と PMAの 同時添加実験を行い, hCG $(\alpha, \beta)$ の $\mathrm{BeWo}$ 細胞内レベルとその分泌レベルに及ぼす影響を検討 した。cholera toxin 添加に伴う hCG $(\alpha, \beta)$ 生成分泌促進は PMA 同時添加によって一層増強 されることを認めたが, $\mathrm{Ca}^{2+}$ ionophore A23187 と PMA の同時添加では有意な変化を観察しなかっ た。

以上の成績より, 䋐毛癌細胞 BeWokおける hCG $(\alpha, \beta)$ 生成分泌制御機構は, cAMP-Akinase 系が主動的役割を担い， $\mathrm{Ca}^{2+}$ - calmodulin 系の関与が hCG $\alpha$ 分泌に限られ，希薄であるが， DG-C-kinase 系は cAMP-A-kinase 系と協調的に作用して, hCG $\alpha$, hCG $\beta$ ならびに hCG の生 成，分泌に対して促進的に働くことが推察された。

ところで, Ritvos ら ${ }^{22}$ は BeWo 細胞において cholera toxin が hCG 分泌を促進し， 12-0-tetradecanoyl phorbol-13-acetate (TPA) も hCG 分泌を TPA 添加から2時間で約2倍に促進すること をまた，Benveniste ら $ら^{8}$ は絨毛癌細胞 JEG-3において PMA が hCG 分泌を軽度促進することを 報告している。しかし，これらの報告はいずれも hCG の分泌レベルに及ぼす影響を論じたもので あり, hCG の subunit レベルで cholera toxin ならびに PMA 添加の影響を絨毛癌細胞内レベルヘ の作用を含めて検討した報告は本論文がはじめてである。一方, Harman ら゙は, trophoblast に

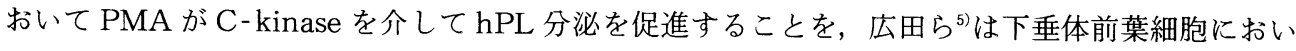
てTPA が C-kinaseを介してLH 分泌を促進することを，またPocotte ら ${ }^{200}$ は副腎髄質の chromaffin 細胞において PMA が catecholamine の分泌を促進することをそれぞれ報告している。さ らに, Ritvos ら ${ }^{22233}$ は BeWo 細胞において PMA により cholera toxin の hCG 分泌促進作用が増 強されることを，また，Byus らは Reuber H35 hepatoma cell において PMA が A-kinase 活性 を増強させることを報告している。 
他方, 広田ら ${ }^{5)}$ は下垂体前葉細胞培養系において TPA 添加群に $\mathrm{Ca}^{2+}$ ionophore A23187 を加える と LH 分泌が TPA 単独添加群の約2倍に増加することを報告し, 他にも, $\mathrm{Ca}^{2+}$ - calmodulin 系と DG-C-kinase 系が協調的に作用する例として，血小板のセロトニン放出反応 ${ }^{9)}$ や肝の glycogen 分 解なとどが知られている。しかし，今回の著者らの成績では BeWo 細胞での hCG $(\alpha, \beta)$ 生成と 分泌レベルに及ぼす $\mathrm{Ca}^{2+}$ ionophore A23187 とPMA の協調的促進効果は観察されなかった。

\section{$\mathrm{V}$ 結 語}

$\mathrm{hCG}(\boldsymbol{\alpha}, \boldsymbol{\beta})$ 生成, 分泌制御機構における細胞内刺激伝達系の役割を解明するため, 絨毛癌細 胞 $(\mathrm{BeWo})$ 培養系飞細胞内刺激伝達系 (cAMP-A-kinase 系, DG-C-kinase 系, $\mathrm{Ca}^{2+}$ - calmodulin 系) それぞれの賦活物質である cholera toxin, phorbol 12-myristate 13-acetate (PMA), $\mathrm{Ca}^{2+}$ ionophore A23187 を添加し，培養液内ならびに培養細胞内 $\mathrm{hCG} \alpha, \mathrm{hCG} \beta, \mathrm{hCG}$ レベルに 及ぼす影響を経時的に検討し，以下の結論を得た。

1) 絨毛癌細胞 (BeWo) では, cholera toxin によって賦活される cAMP-A-kinase が，まず細 胞内 $\mathrm{hCG} \alpha$ レベルを著しく増加させたあと, 細胞内 $\mathrm{hCG} \beta$ レベルを, 次いで細胞内 $\mathrm{hCG}$ レベル をそれぞれ大きく増加させ，同時にその分泌レベルを細胞内レベルの変化と同一の時間的推移で著 明に促進させることより, cAMP-A-kinase は hCG $(\alpha, \beta)$ 分泌機構のみならず hCG $(\alpha, \beta)$ 生成機構の中でも主動的役割を担い, 䋐毛癌細胞での $\mathrm{hCG}(\alpha, \beta)$ 生成と分泌は連動関係にある ことが認められた。

2) cholera toxin 添加に伴ら䄉毛癌細胞 (BeWo) 内 hCG $(\alpha, \beta)$ レベルとその分泌レベルの増 加は, DG-C-kinase 系の賦活剤である PMA の同時添加によっていずれも一層顕著となることよ $\eta$, 䄉毛癌細胞 $(\mathrm{BeWo})$ の hCG $(\alpha, \beta)$ 生成, 分泌制御機構の中で, DG-C-kinase 系は cAMP -A-kinase 系と協調的に作用し促進的に働くことが推察された。

3） $\mathrm{Ca}^{2+}$ ionophore A23187 によって賦活される $\mathrm{Ca}^{2+}$ - calmodulin 系は䄉毛癌細胞 (BeWo) での $\mathrm{hCG} \alpha$ 分泌に促進的に関与するが，その生成制御機構への関与は希薄であった。

\section{謝辞}

本研究の一部は文部省科学研究費補助金（一般研究 C-61570796, C-0267074）により援助され た。

\section{文献}

1) Byus, C.V., Trevillyan, J.M., Cavit, L.J. and Fletcher, W.H.: Activation of cyclic adenosine 3' 5' -monophosphate-dependent protein kinase in H35 hepatoma and Chinese hamster ovary cells by a phorbol ester tumor promoter. Cancer Res. , 43: 3321-3326, 1983.

2) Futamura, K., Maruo, T. and Mochizuki, M.: Differential effects of dibutyryl cyclic AMP and epidermal growth factor on the synthesis and secretion of human chorionic gonadotropin and its subunits by trophoblastic and non-trophoblastic cells. Acta Obstet. Gynecol. Jpn., 39: 1641-1648, 1987.

3) Garrison, J.C., Johnsen, D.E. and Campanile, C.P.: Evidence for the role of phosphorylase kinase, protein kinase C, and other $\mathrm{Ca}^{2+}$-sensitive protein kinases in the response of hepatocytes to angiotensin II and 
vasopressin. J. Biol. Chem., 259: 3283-3292, 1984.

4) Harman, I., Zeitler, P., Ganong, B., Bell, R.M. and Handwerger, S.: Sn-1,2-diacylglycerols and phorbol esters stimulate the synthesis and release of human placental lactogen from placental cells: a role for protein kinase C. Endocrinology, 119: 1239-1244, 1986.

5）広田憲二, 青野敏博,

池上博雅，門脇浩三，谷澤 修：下垂体 gonadotropin 分泌と protein kinase C. ホルモンと臨床， 34: 365-369, 1986.

6) Holmgren, J.: Actions of cholera toxin and the prevention and treatment of cholera. Nature, 292: 413-417, 1981.

7) Hussa, R.O.: Biosynthesis of human chorionic gonadotropin. Endocrine Rev., 1: 268-294, 1980.

8) Ilekis, J. and Benveniste, R.: Effects of epidermal growth factor, phorbol myristate acetate, and arachidonic acid on chorionic gonadotropin secretion by cultured human choriocarcinoma cells. Endocrinology, 116: 2400-2409, 1985.

9）川原康洋, 津田

孝, 高井義美 : diacylglycerol, $\mathrm{Ca}^{2+}$ と cyclic AMP. 最新医学, 40:296-303, 1985.

10) Kikkawa, U., Takai, Y., Miyake, R. and Nishizuka, Y.: Protein kinase $C$ as a possible receptor protein of tumor-promoting phorbol esters. J. Biol. Chem., 258: 11442-11445, 1983.

11) Kishimoto, A., Takai, Y., Mori, T., Kikkawa, U. and

Nishizuka, Y.: Activation of calcium and phospholipid-dependent protein kinase by diacylglycerol, its possible relation to phosphatidylinositol turnover. J. Biol. Chem., 255: 2273-2276, 1980.

12) Maruo, T., Segal, S.T. and Koide, S.: Studies on the apparent human chorionic gonadotropin-like factor. Endocrinology, 104: 932-939, 1979.

13) Maruo, T., Matsuo, H., Ohtani, T., Hoshina, M. and Mochizuki, M.: Differential modulation of chorionic gonadotropin (CG) subunit mRNA levels and CG secretion by progesterone in normal placenta and choriocarcinoma cultured in vitro. Endocrinology, 119: 855-864, 1986.

14) Maruo, T., Matsuo, H., Oishi, T., Hayashi, M., Nishino, R. and Mochizuki, M.: Induction of differentiated trophoblast function by epidermal growth factor: Relation of immunohistochemically detected cellular epidermal growth factor levels. J. Clin. Endocrinol. Metab., 64: 744-750, 1987.

15) Maruo, T., Hoshina, M. and Mochizuki, M.: Differential regulation of chorionic gonadotropin subunit mRNA levels and secretion by gonadal steroids and growth factors in normal and malignant trophoblasts. Bellet D. and Bidart J.M. (ed.) In Structure-Function Relationship of Gonadotropins, Raven Press, New York, 1989, p.191-208.

16) McCaffrey, P.G., Friedman, B. and Rosner, M.R.: Diacylglycerol modulates binding and phosphorylation of the epidermal growth factor receptor. J. Biol. Chem., 259: 12502-12507, 1984. 17) Nishizuka, Y.: The role of protein kinase C in cell surface signal transduction and tumour promotion. Nature, 308:693-698, 1984.

18) Nishizuka, Y.: Studies and perspectives of protein kinase C. Science, 233: 305-312, 1986. 19) Pattilo, R.A. and Gey, G.O.: The establishment of a cell line of hormone-synthetizing trophoblastic cells in vitro. Cancer Res., 28: 1231-1236, 1968.

20) Pocotte, S.L.: Effects of phorbol ester on catecholamine secretion and protein phosphorylation in adrenal medullary cell cultures. Neurobiology, 82: 930-934, 1985. 
21) Reed, P.W. and Lardy, H.A.: A23187:A divalent cation ionophore. J. Biol. Chem., 247: 6970-6977, 1972.

22) Ritvos, O., Jalkanen, J., Huhtaniemi, I., Stenman, U., Alfthan, H. and Ranta, T.: 12-O-tetradecanoyl phorbol-13-acetate potentiates adenosine 3', 5' -monophosphate-mediated chorionic gonadotropin secretion by cultured human choriocarcinoma cells. Endocrinology, 120: 1521-1526, 1987.

23) Ritvos, O., Jalkanen, J., Pekonen, F., Stenman, U. and Ranta, T.: Epidermal growth factor but not insulin-like growth factor-I potentiates adenosine 3',5'-monophosphate-mediated chorionic gonadotropin secretion by cultured human choriocarcinoma cells. Endocrinology, 123: 859-865, $1988 . \quad 24)$ Sawyer, S.T. and Cohen, S.: Enhancement of calcium uptake and phosphatidylinositol turnover by epidermal growth factor in A-431 cells. Biochemistry, 20:6280-6286, 1981. 25) TerBush, D.R. and Holz, R.W.: Effects of phorbol esters, diglyceride, and cholinergic agonists on the subcellular distribution of protein kinase $\mathrm{C}$ in intact or digitonin-permeabilized adrenal chromaffin cells. J. Biol. Chem., 261: 17099-17106, $1986 . \quad 26)$ Tojo, S., Mochizuki, M. and Maruo, T.: Chorionic gonadotropin produced from the cultivated trophoblasts. In: Moudgal N.R. (ed.) Gonadotropins and Gonadal Function, Academic Press, New York, 1974, p.321-331.

(受付日 : '90.10.17)

（採択日：'90.12.26） 